\title{
TRENDS IN BUDGET CAPACITY BUILDING AND DEVELOPMENT
}

\author{
IRINA ISHINA
}

All-Russian state tax academy of the Russian Federation, Ministry of Finance, Moscow, Russia

\section{ABSTRACT}

In the article is regarded the question concerning the mechanism of budgetary regulation of cumulative budgetary potential of regions. The economic maintenance of forms and methods of budgetary regulation, proceeding from specificity of construction of budgetary and tax system of the Russian Federation is opened.

\section{JEL CLASSIFICATION \& KEYWORDS}

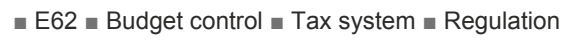

\section{INTRODUCTION}

The internal structure of the mechanism of budget control or its organization system stipulate its following forms and methods that facilitate the process of building a cumulative regional budget capacity on a new qualitative basis (Fig.1).

\section{Budget capacity}

The main direct action forms inherent in the budget control mechanism used in formation of regional budgets include the tax regulation and transfer regulation.

Since taxes are a significant component of a cumulative budget capacity of a number of Russian Federation subjects (in this case sources and procedures of tax revenue formation are immaterial), the tax regulation acts as the principal form of the budget control mechanism implementation though it can be also viewed as a separate control mechanism. Speaking about the tax regulation, it should be noted that the authors of one of monographs rightly emphasized [1] that "at present Russian law-makers do not have clear-cut principles of revenue appropriation to budgets of different levels. As a result, the reasons that caused assignment of taxes to one or another group remain unclear. The composition of federal taxes is most likely determined by the fiscal factor. Tax payments that ensure the biggest amounts of receipts are assigned to federal taxes". By way of illustration we might take the value-added tax that accounts for more than half of all tax revenues of the federal budget.

Moreover, existing methods of allocation and re-allocation of taxes make it impossible to realize one of the root principles, namely that of self-dependence, lying in the basis of building the budget federalism and inter-budget relations and being at the same time the basic principle for a budget system in the whole. A very high degree of centralization in the taxation field (characteristic, as a rule, of a unitary state) actually deprives regional authorities of the ability to form their budgets independently as well as define financial priorities of socio-economic development.

A tendency to tax revenues concentration at the federal level has been traced quite vividly in the recent years. Changes in the budget and tax legislation of Russia that came into force in 2001-2009 further enhanced this tendency. The high concentration of funds in the federal budget at the stage of primary distribution of taxes along the budget system vertical

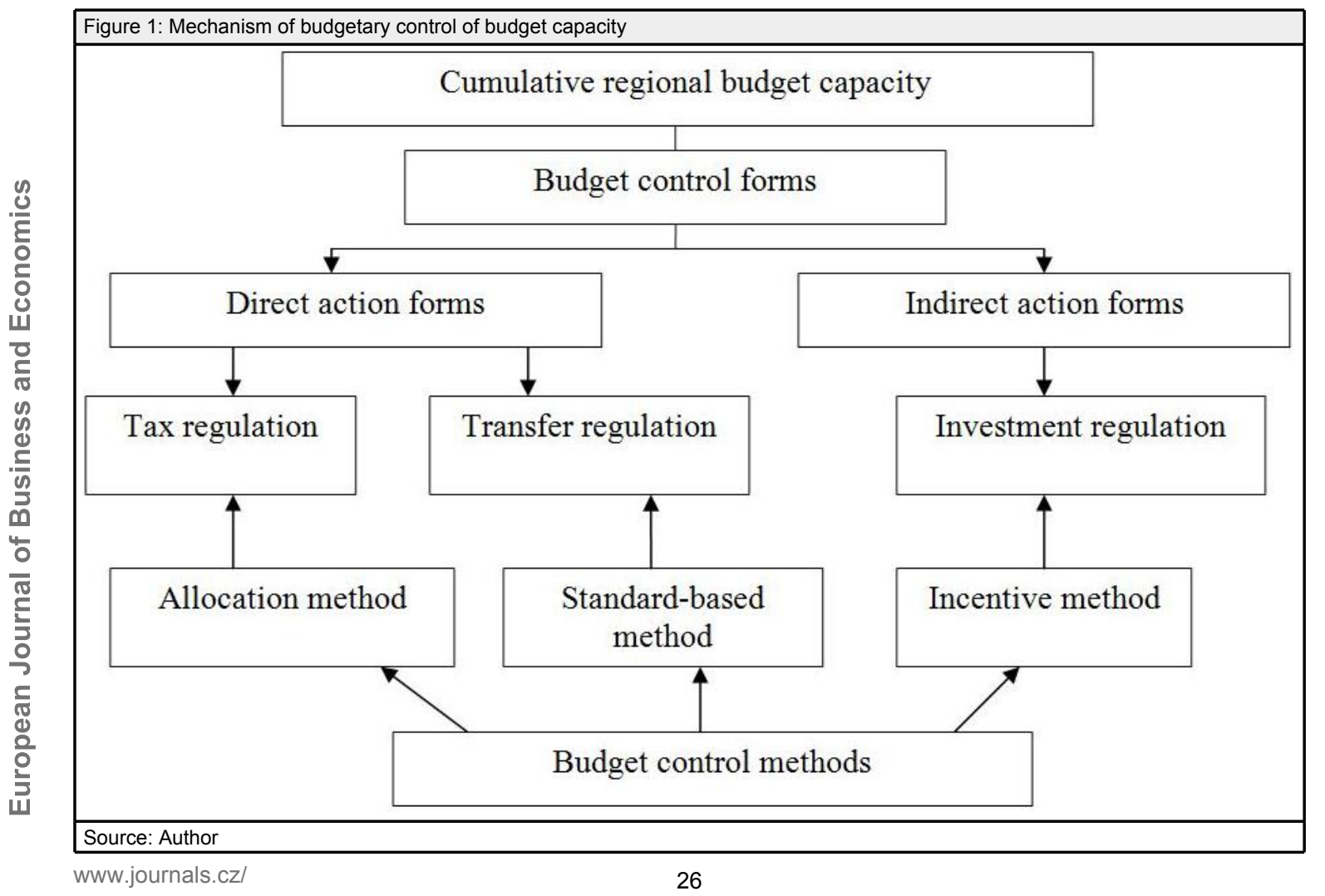


has risen to a still higher value. At the same time it should be mentioned that in one of the program document chapters [2] a need has been declared to enhance the role of regional and local budgets, including tax budgets, in order to create conditions for future formation of revenues for budgets of every level, based, primarily, on own taxes. At present, according to Ch.47 of the Russian Federation Budget Code [3], all taxes coming into budgets of Russian Federation subjects, irrespective of their status, are formally regarded as a subject's own taxes but in fact they are formed by way of re-distribution of federal taxes.

Meanwhile, regions that bear the majority of expenditure responsibilities, primarily of social nature, lack own financing sources, which increases their exposure to receipts from the federal budget and makes it impossible for them to implement the budget balance principle independently; therefore, in practice regional budgets are actually formed based on the leftover principle.

As a result, the socio-economic purpose of budgets of the Russian Federation subjects is reduced to accumulation of financial resources generated at a given area and transferred to regional budget-and-tax systems in the whole through a single channel. Moreover, budgets of RF subjects concentrate tax revenues arriving in accordance with an accepted procedure of their distribution between budget systems of different levels. The procedure of breaking down federal taxes by the budget system levels has been established by the Russian Federation Budget Code and laws "On the Federal Budget" passed annually.

The main source of tax revenues for the majority of the RF subjects are federal taxes, which makes regional budgets dependable on federal administration bodies, prevents them from reaching actual self-dependence along with decentralization of interbudget relations. Therefore, the development of the tax control mechanism should focus specifically on enhancement of the role of regional (local) taxes in formation of tax revenues of the RF subjects. Probably, it makes sense to put to practice the "one tax-one budget" approach.

It is obvious that the state plays here a decisive role because the issues of increasing the significance of regional (local) taxes at formation of a cumulative budget capacity can be solved only through the state legislation, and there are different solution models applicable. One of the solutions can be dedication of a definite group of taxes to each budget level. For instance, instead of the corporate profit tax and the personal income tax being now federal taxes a regional profit and income tax might be introduced, which will create conditions to reduce differentiation in budget sufficiency levels of individual regions.

The next model is concerned with increasing the quantity of taxes imposed and collected at the regional level, similar to what happened at the first stages of the tax system formation in modern Russia that was characterized by multiplicity of collected taxes imposed by legislative resolutions of regional (municipal) administrations which were usually collected, especially at a local level, from the net income remaining in companies after payment of all mandatory taxes and charges and other regular payments. The latter approach, however, increases the tax burden of economic agents and tends to reduce their financial and business activities since taxes are one of the most important state limitations that effect the desire to work efficiently and accumulate capital to be invested into future development of businesses. Following the thesis generally recognized abroad that an encouraging tax policy guarantees growth of investments, decisions in the tax regulation sphere should be directed towards encouraging the policy of stimulation and development of private capital investments to efficiently supplement the policy of budget control pursued by RF subjects. According to researchers [4], such an exceptionally significant problem as self-sufficiency of regions must be solved by active use of potentials of all forms of property, and this has to become one of the budget control priotities. As to the private capital accumulation, it is in many respects determined by a regional tax policy which is an indispensable element of regional anti-crisis regulation. Therefore, the specifics of the current phase of the budget control development, concerning its tax component, should require differentiated tax rate cutting aimed simultaneously at equalizing gaps between regions. It will obviously cause temporary reduction of regional budget receipts and hence increase exposure to other sources of cumulative budget capacity formation but the effect will be absolutely opposite in the long run: low taxes will stimulate the production growth resulting in expansion of the taxable base and hence in increase of budget receipts.

Therefore, further tax system reform measures that could make taxes more flexible, stable and clear seem inevitable. Opponents of this approach may appeal to the growth under these conditions of a budget deficit predicted to be $3.6 \%$ of the GDP in the next year, which may be compared, for instance, with $12.5 \%$ of the GDP in the USA, $10 \%$ in the OECD, whereas in China this index has grown tenfold for the last year. But the above examples of countries having considerably higher budget deficit values, as compared to Russia, prove that even an economic situation like that can demonstrate examples of successful modernization of the economy as well as technological, investment and innovation development. A conclusion can be made that the fiscal function of taxes should not be predominant and it should be implemented together with regulating and stimulating functions.

The main objectives of budget control through a regional taxation system should be the following:

- Expansion of a taxable base by increasing the number of tax payers, taxable incomes,

- tax policy conformance to priorities of the structural policy in regions,

- easing of the tax burden and tax system streamlining by canceling low-efficiency taxes or replacing them with other taxes (for instance, the gaming tax that can be collected in a limited number of the RF subjects may be replaced by a regional tax on economic agent profits),

- extension of a package of measures related to tax collection, non-payments and tax law enforcement,

- introduction of radically new technologies of taxation activities on a computer network basis.

The above objectives of the regional tax system enhancement should be supported by a theoretically grounded strategy of structural reforms in regions. Their performance effectiveness is achieved through efficient activities of production-economic complexes and various type enterprises and creation of their rational structure.

Restructuring of the economy is a matter of particular importance and a factor of stabilization providing conditions for steady development of RF subjects in the future. The stabilization program of regional development should be aimed at elimination of structural disproportions in regions caused by non-conformance of existing ossified structures to transformations that occurred in economies of regions and in the country's economy in the whole. It is smoothing 7 
out such disproportions in economies of individual areas that could be looked upon as a reserve for steady development of the base for cumulative budget capacity formation. The structural transformation should be reduced to quantitative and qualitative changes of structures, shifting of accents, i.e. identifying new priorities in economic development to meet the needs and interests of a region, as well as to anti-crisis management of economic agents engaged in certain types of economic activities along with reduction, if needed, of their production volumes and capacities. To facilitate implementation of development strategies of the RF subjects, the Russian Ministry of Regional Development intends to introduce a logically bound system of strategic planning documents adjusted to and matching each other. At present, work is already in progress on development of socio-economic development strategies for federal regions and macroregions. A particular emphasis in them is laid on implementation of interregional projects based on the so-called fields of common interests of different areas.

In smoothing out serious disproportions in the economic development of certain RF subjects the decisive part may be played by the investment component of budget control which has an indirect effect on stimulation of budget self-sufficiency of regions and strengthening their independence in development of the economic base. This form of budget control is specifically targeted at ensuring self-sufficiency of regions and providing regional authorities with their own reliable sources of budget revenues that could be actually under their control and used for the purpose of building an economic base for filling up the cumulative budget capacity.

The use of the investment component of budget control along with incentive methods in the part of taxation, the integration of investment projects into targeted complex programs of regional development might solve region self-sufficiency problems. In this situation the tax component and the budget component of budget control are interrelated since the aim of investments is formation of the production potential of areas and creation of economic conditions for building the taxable base.

And priority should be given to economic activity fields that make maximum use of local raw material resources for production of items enjoying demand on the domestic and foreign markets to encourage the growth of working places being points of growth in RF subjects.

The above approach is substantiated by the world experience oriented at stimulation of points of growth in all territories, encouraging actual growth of their economies and the social sphere. The key financial resource here is budget funds capable of providing a good incentive for investment activities of RF subjects.

These activities may have various forms such as development of infrastructure-industrial clusters, finished financial products or service packages including off-budget resources to be provided to business under certain conditions for implementation of projects of territorial development capable of changing the structure of a regional economy in favor of high-technology industries.

Among the areas that have succeeded in implementation of large-scale investment projects are the Kaluga Area and the Republic of Tatarstan. In these areas favorable business conditions and the needed infrastructure have been created, and it makes sense to duplicate their experience so as to cover the whole country.
Today there exist many well-known instruments of government support of investment projects. They are used by various authorities; for every instrument there are specific procedures of project selection, criteria of efficiency and project control. The Concept of a Long-Term SocioEconomic Development of the Russian Federation until 2020 [5] suggests coordination and matching of all instruments within the framework of one project, with coordination responsibilities imposed on the RF Ministry of Regional Development. According to this Concept, the basis for the long-term investment planning in federal districts should be laid by selection of priority development zones, in other words, by identifying potential points of growth of a regional economy. One of the instruments to stimulate territorial investment activities will be creation of infrastructure-industrial clusters to be used as benchmarks in implementation of big regional projects.

\section{Conclusion}

Within the scope of these documents, development strategies of the RF subjects should match each other and be adjusted to development strategies of the country's economy and social sphere.

One of the components of strategic planning will be keeping record of the use of public-private partnership mechanisms, and particularly at this stage mutual obligations of parties have to be reached and recorded.

Another important aspect is the necessity of matching strategic and territorial planning. To this end, region development strategies should become the basis for development of territorial planning scenarios of RF subjects. This principle has been put into the Draft Law "On State Strategic Planning".

The above measures, if taken, will be able to ensure predictability of area development for investors so that they could proceed to long-term planning of their investments.

In view of the above, a course planned in the budget control framework means stimulation of economic development of regions and, in the lesser degree, passive financial aid. This course anticipates improvement of budget self-sufficiency of regions, reduction of transfer recipients and growth of the investment component of the federal budget expenditures.

\section{REFERENCES}

1. Russian Tax Law: Textbook under the editorship of Y.A.Krokhina. Moscow: Norma, 2003.

2. Program for the Development of Fiscal Federalism in the Russian Federation. "Collected Legislation of the Russian Federation", 20.08.2001, № 34, art.3503.

3. RF Budget Code. "Collected Legislation of the Russian Federation", 1998, №31, art. 3823. (ed. 24.07.2008).

4. Chernik, D.G., Shmelev, Y.D. Taxes and Taxation: Training Manual. - Moscow:, Voentekhinizdat, 2009.

5. Concept of Long-term Socio-Economic Development of the Russian Federation for the period until 2020. "Collected Legislation of the Russian Federation”, 24.11.2008, № 47, art. 5489. 